\title{
The enfant terrible of genetics
}

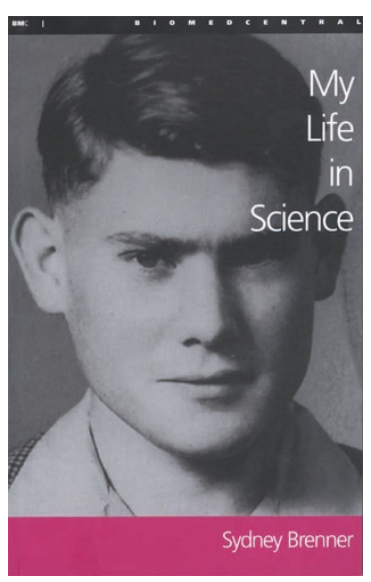

\author{
My Life in Science \\ by Sydney Brenner \\ BioMed Central Ltd $\cdot 2001$ \\ Hardback £14.99/\$21.00 \\ John White
}

A $\mathrm{t}$ a recent post-symposium reception, I was talking to one of the participants when the conversation drifted towards our scientific pedigrees, as so often happens. When I revealed the identity of my graduate advisor, the response was immediate and spontaneous: "Ah, Sydney Brenner, the greatest scientist who never won the Nobel Prize". This was not an isolated incident. Brenner is very much a scientist's scientist, long recognized by many as one of the truly outstanding scientists of our age. In the course of my scientific career I have encountered many distinguished people. Most did not live up to their reputations. Brenner was different, he seemed larger than life: an extraordinary combination of energy, wit, charisma, mischief and fun. Many, including myself, were seduced by this unique combination into radically changing the direction of our careers, often to our considerable satisfaction.

Brenner was born in Germiston, a small town near Johannesburg. Although his father, a cobbler, was illiterate, he may have been the source of Brenner's vitality as he plied his craft into his 80's. Brenner learned to read at the age of four from newspapers used as a tablecloth in a room where a friend of his mother lived. Brenner advanced rapidly in school and went to medical school in Johannesburg when he was 14 years old. It was here that his interest in biology was really ignited by such classic works as Needham's Biochemistry and Morphogenesis (Cambridge), which he read out loud during lunch breaks with his mentor, Joseph Gillman.

Brenner moved on to Cyril Hinchelwood's laboratory in Oxford after medical school. It was here that he started working on bacteriophages. While in England, Brenner became aware of the dawning of the new age of molecular biology heralded by Watson and Crick's model of the structure of DNA and its profound implications. After finishing his $\mathrm{PhD}$ and returning to South Africa, Brenner soon returned to England to work in the Cavendish Laboratories of the Medical Research Council with Francis Crick. These two giants of science seemed to have developed a strong mutual respect for each other from the beginning and went on to share an office for twenty years.

Brenner's early career in Cambridge produced some truly classic science. In collaboration with François Jacob and Matt Meselson, messenger RNA was postulated and then demonstrated to exist. In collaboration with Francis Crick and Lesley Barnett, the codon (Brenner's word) was shown to be three bases in length.

In the early 1960s, after the genetic code was solved, many of the luminaries of molecular biology turned their attention to questions of cell, developmental or neurobiology. Brenner, with characteristic panache and courage decided to mount an assault on all these fields. He reasoned that the lessons learned from using genetics on simple model organisms to study fundamental questions of molecular biology could be applied to the study of cell, developmental and neurobiology most effectively if an appropriate model organism could be found. He sought an organism with a short lifespan that would be amenable to genetic analysis and small enough so that its anatomy and development could studied at the level of individual, identified cells. The organism he chose was, of course, the nematode Caenorhabditis elegans. I often hear Brenner's justification for choosing C. elegans repeated almost as a litany when listening to a seminar from one of the 1000 or so scientists currently studying this organism. Brenner succeeded in launching studies of C. elegans into what has come to be a major world enterprise by the strength of his vision, his extraordinary charisma, and sheer hard work. Brenner's enthusiasm was highly infectious; postdocs came to Cambridge and left to set up their own C. elegans labs all over the world.

Brenner's restless energy kept him moving on. After it was clear that the
C. elegans enterprise was self-sustaining, Brenner moved away from the field, having become fascinated with the newly discovered potential of gene cloning in the mid 1970s. This interest evolved into a fascination with whole organism genomics. In characteristic style he selected an organism that he considered optimal for studying vertebrate sequences - the fugu fish; an organism that probably has around the same number of genes as any other vertebrate but has eightfold less DNA.

I was delighted to hear that Brenner had written an autobiography. After receiving it, however, I was a little disappointed to find that this book was a transcript of a 15-hour interview by Lewis Wolpert that was liberally peppered with exclamation marks. But my disappointment was short lived. Reading it, I was immediately transported back thirty years to the 10 o'clock show in the coffee room of the MRC where Brenner would delight, entertain and inform us with his inimitable monologues. Brenner loves talking and feeds on an audience. He claims that many of his ideas arise in the course of conversations where they become honed and refined by scientific discourse. He is a gifted impersonator with a mischievous sense of humour. Much of his humour and personality come across in this book in a way that would be stifled in a more conventionally presented autobiography. The editors have done a good job of fleshing out Brenner's "stream of unconsciousness" with some historical fillers. Overall this delightful book is highly entertaining and informative, and gives a unique insight into the mind and personality of one of the most influential and colourful scientists of our time during a period of scientific revolution that radically changed the world.

John White is in the laboratory of Molecular Biology, University of Wisconsin, 1975

Observatory Drive, Madison, WI 53706, USA e-mail: jwhite1@facstaff.wisc.edu 